\title{
The Effects of Congenital Deafness on Auditory Nerve Synapses: Type I and Type II Multipolar Cells in the Anteroventral Cochlear Nucleus of Cats
}

\author{
Elizabeth E. Redd, Hugh B. Cahill, Tan Pongstaporn, and David K. Ryugo \\ Center for Hearing Sciences, Johns Hopkins University School of Medicine, Baltimore, MD 21205, USA
}

Received: 13 September 2001; Accepted: 7 January 2002; Online publication: 26 March 2002

\section{ABSTRACT}

Sensory deprivation has been shown to exert detrimental effects on the structure and function of central sensory systems. Congenital deafness represents an extreme form of auditory deprivation, and in the adult white cat, synapses between auditory nerve endings and resident cells of the anteroventral cochlear nucleus exhibited abnormal structure. Endbulbs of Held were reduced in branching and displayed striking hypertrophy of their postsynaptic densities. So-called modified endbulbs showed no change in branching complexity but did exhibit hypertrophy of their postsynaptic densities. These differential pre- and postsynaptic effects prompted the question of how deafness might affect other primary endings and synapses. Thus, we studied type I and type II multipolar cells that receive bouton endings from auditory nerve fibers. Type I multipolar cells project to the contralateral inferior colliculus and have relatively few axosomatic endings; type II multipolar cells project to the contralateral cochlear nucleus and have many axosomatic endings. Compared with normal-hearing cats, bouton endings of congenitally deaf cats were smaller but there was no difference in synaptic vesicle density or size of postsynaptic densities. These data reveal that different classes of primary endings and second-order

Correspondence to: Dr. David K. Ryugo • Center for Hearing Sciences • Johns Hopkins University School of Medicine • Traylor Research Building • 720 Rutland Avenue • Baltimore, MD 21205. Telephone: (410) 955-4543; fax: (410) 614-4748; email: dryugo@ bme.jhu.edu neurons exhibit different degrees of synaptic anomalies to deafness.

Keywords: auditory nerve fibers, boutons, hearing, postsynaptic densities, primary endings

\section{INTRODUCTION}

The role of environmental sound on normal development of the central auditory system remains a subject of intense research interest. Auditory deprivation in the developing animal produces severe abnormalities in the central pathway, whereas older animals are less affected (e.g., Powell and Erulkar 1962; Rubel and Parks 1988; Sie and Rubel 1992; Kelley et al. 1997; Ryugo et al. 1997; Sininger et al. 1999; Marianowski et al. 2000; Zirpel et al. 2000). Clinical observations related to the basic research suggest that the best candidates for cochlear implants are very young children or those who developed some linguistic skills before becoming deaf (Waltzman et al. 1991; Niparko et al. 2000). The implication is that sensory stimulation, whether natural or prosthetic, is necessary during early life to ensure the normal development of the central auditory system.

In an effort to study the influence of acoustic stimulation on the developing brain, there have been experimental manipulations on the end organs to deprive the system of inputs. Surgical and pharmacologic manipulations of the auditory periphery produced deafness and resulted in cell atrophy and loss (Trune 1982a,b; Lustig et al. 1994; Russell and Moore 1999; Hardie and Shepherd 1999), abnormal 
axonal projections (Nordeen et al. 1983; Moore and Kitzes 1985; Russell and Moore 1995), and synaptic anomalies (Hardie et al. 1998). These manipulations, however, are accompanied by potential complications such as indirect surgical trauma or nonspecific drug effects. In this context, the congenitally deaf white cat (DWC) represents a useful alternative for these kinds of studies (Bosher and Hallpike 1965; Brown et al. 1971; West and Harrison 1973; Mair 1973; Schwartz and Higa 1982; Ryugo et al. 1997, 1998; Heid et al. 1997; Redd et al. 2000).

The congenital defect in DWCs is identified by pigmentation abnormalities (white fur, heterochromic irides), cochleosaccular degeneration, and autosomal dominant transmission with incomplete penetrance (Rawitz 1896; Wolff 1942; Bosher and Hallpike 1965; Bergsma and Brown 1971). The cochlear pathology of the DWC ranges from moderate hair cell loss to complete collapse of the organ of Corti with corresponding degrees of hearing loss (Bosher and Hallpike 1965; Mair 1973; Pujol et al. 1977; Rebillard et al. 1981; Ryugo et al. 1998). There is variable loss of spiral ganglion cells and atrophic structural changes in neurons of the cochlear nucleus (West and Harrison 1973; Larsen and Kirchhoff 1992; Saada et al. 1996; Ryugo et al. 1997) and superior olivary complex (Schwartz and Higa 1982). Although the pattern of ascending auditory projections in the brainstem of DWCs appears normal (Heid et al. 1997), there are different degrees of synaptic abnormalities in different cell classes in the cochlear nucleus (Ryugo et al. 1997, 1998; Redd et al. 2000). Importantly, these animals appear normal in all other aspects.

In the cat cochlear nucleus, we previously demonstrated that two auditory circuits had different reactions to congenital deafness (Ryugo et al. 1997, 1998; Redd et al. 2000). One circuit involved spherical bushy cells and the large axosomatic endings, endbulbs of Held. These components are implicated in the processing of interaural time differences (Irvine 1986, 1992; Yin and Chan 1988), and they were obviously altered in the DWCs. Compared with normal-hearing cats, endbulb synapses exhibited a reduction in synaptic vesicles and a striking hypertrophy of the postsynaptic density in spherical bushy cells (Ryugo et al. 1997, 1998). In contrast, the so-called "modified" (smaller) endbulbs and globular bushy cells are associated with a pathway implicated in the processing of binaural level differences (Boudreau and Tsuchitani 1968; Irvine 1992). The synapses at this station exhibited a mild increase in synaptic vesicle number and a modest but statistically significant hypertrophy of the postsynaptic density (Ryugo et al. 2000). As a continuation of this research, we describe the synaptic morphology of bouton endings that contact type I and type II multipolar cells in the anteroventral cochlear nucleus (AVCN) of normal-hearing and congenitally deaf white cats.

\section{MATERIALS AND METHODS}

\section{Animal subjects}

Four male cats with white coats, green eyes, and a family history of deafness represented the congenitally deaf population. The ages of these cats were 6 months, 9 months, 12 months, and 6.5 years. The 6 month-old cat and the 6.5-year-old cat provided endbulb and modified endbulb data to previous studies, which illustrated synaptic changes for spherical and globular bushy cells (Ryugo et al. 1997, 1998). All white cats in this study were defined as deaf because they exhibited no click-evoked auditory brain stem responses (ABRs) up to $99 \mathrm{~dB}$ SPL, and, upon histologic inspection, the organs of Corti were completely degenerate. Each DWC received an extracellular injection of horseradish peroxidase (HRP) injections into its auditory nerve. For comparison, 10 pigmented cats with normal thresholds for clickevoked ABRs, ranging in age from 6 months to 5.75 years, were used. Four cats had auditory nerve injections, two had unilateral inferior colliculus injections, and four had unilateral cochlear nucleus injections. All of the cats had clean external and middle ears with no signs of infection to otoscopic exam. Animal procedures were approved by the Johns Hopkins University Animal Care and Use Committee and were in strict accordance with the guidelines established by the NTH.

\section{Auditory brain stem responses}

Each cat in this study had its hearing tested. Behaviorally, the white cats did not respond to any auditory stimuli. Cats were sedated with $25 \mathrm{mg} / \mathrm{kg}$ intramuscular ketamine hydrochloride and $0.5 \mathrm{mg} / \mathrm{kg}$ intramuscular xylazine and placed in a soundproof chamber. Sterile needle electrodes were inserted, one behind each ear and one at the vertex. The ground wire was inserted into the nasal dorsum skin. ABR click recordings were made between the vertex electrode and the ipsilateral ear, and standard ABRs were collected and averaged from 1000 clicks (Tucker Davis Technologies, Inc., Asheville, NC). Clicks were generated by passing a $100 \mu$ s pulse into attenuators with a maximum output at the headphones of $99 \mathrm{~dB}$ peak SPL using a closed acoustic system (Sokolich; 1977). The four white cats had profound hearing loss (at least $99 \mathrm{~dB}$ SPL in the deaf ear) and the pig- 
mented cats had normal-hearing thresholds $(5-10 \mathrm{~dB}$ SPL).

\section{Animal preparation and extracellular injections}

Cats were initially sedated with intramuscular injections of xylazine hydrochloride $(0.5 \mathrm{mg} / \mathrm{kg})$ and ketamine hydrochloride $(25 \mathrm{mg} / \mathrm{kg})$. Atropine $(0.25 \mathrm{cc}$ IM) was administered to reduce secretions. Thereafter, anesthesia was induced with an intraperitoneal injection $(0.4 \mathrm{cc} / \mathrm{kg}$ body weight) of diallyl barbituric acid $(100 \mathrm{mg} / \mathrm{mL})$ in urethane solution $(400 \mathrm{mg} /$ $\mathrm{mL}$ ). Areflexia to paw pinches was maintained by 0.1 cc IP injections as needed. Body temperature was monitored by a rectal thermometer and kept at approximately $39^{\circ} \mathrm{C}$ using a heating pad and heated $\left(28^{\circ} \mathrm{C}\right)$ soundproof chamber.

For each cat, the trachea was cannulated via tracheostomy, an intravenous line was placed in the cephalic vein for administration of balanced salt solutions, and the head was fixed in a special holder. The skin, muscle layers, and aponeuroses were removed over the skull and dissection continued to each external meatus. In 4 DWCs and 4 normalhearing cats, the posterior cranial fossa was opened with rongeurs exposing the cerebellum, the dura was reflected, and the cerebellum was retracted on one side to expose the auditory nerve. A $30 \%$ solution of HRP in 0.05 Tris buffer ( $\mathrm{pH} 7.3$ ) was injected by passing $5 \mu \mathrm{A}$ of positive current $(7 \mathrm{~s}$ on, $50 \%$ duty cycle) for $5 \mathrm{~min}$ through a micropipette (inside diameter-40 $\mu \mathrm{m}$ ) that was inserted directly into the auditory nerve. In two other cases, the cerebellum was aspirated on one side to expose the right inferior colliculus, and $2 \mu \mathrm{L}$ of $30 \% \mathrm{HRP}$ was injected using a $5 \mu \mathrm{L}$ Hamilton syringe. For the final four cases, 1-1.5 $\mu \mathrm{L} 30 \%$ HRP was unilaterally injected into the cochlear nucleus using the same $5 \mu \mathrm{L}$ syringe.

\section{Tissue preparation}

Between 20 and 24 hours after HRP was injected, each cat was given a lethal dose of anesthesia (sodium pentobarbital, $75 \mathrm{mg} / \mathrm{kg}$ body weight, IP), the heart was surgically exposed, and heparin sulfate $(0.1 \mathrm{cc})$ was injected directly into the heart. Approximately $50 \mathrm{cc}$ of $0.1 \mathrm{M}$ phosphate-buffered saline ( $\mathrm{pH} 7.4)$ containing $1 \%$ sodium nitrite (a vasodilator) was perfused intracardially, followed immediately by approximately $1.5 \mathrm{~L}$ of fixative containing $2 \%$ paraformaldehyde and $2 \%$ glutaraldehyde in $0.1 \mathrm{M}$ phosphate buffer.

All brains were postfixed overnight in fresh fixative at $5^{\circ} \mathrm{C}$. After removal from the skull, the brain stems were bisected and embedded in a gelatin-albumin mixture hardened with glutaraldehyde. In brains with an auditory nerve injection, cochlear nucleus sections were cut at a thickness of $50 \mu \mathrm{m}$ on a Vibratome oriented parallel to the lateral surface of the nucleus ("strial" axis of Blackstad et al. 1984); all other brains were sectioned at a thickness of $50 \mu \mathrm{m}$ in the coronal plan, including the midbrain, pons, and medulla. Sections were collected in serial order in $0.1 \mathrm{M}$ phosphate buffer, washed in the same buffer several times, and incubated for $60 \mathrm{~min}$ in phosphatebuffered $0.05 \%$ 3,3'-diaminobenzidine (DAB, Sigma Chemical ca, St. Louis, MO, grade II Tetra $\mathrm{HCl}$ ) activated with hydrogen peroxide. Sections were washed multiple times with $0.1 \mathrm{M}$ phosphate buffer and processed for electron microscopy as detailed below. Alternate sections through the inferior colliculus and cochlear nuclei were mounted on slides, counterstained with cresyl violet, and used for light microscopic verification of the injection site. The other sets of sections through the cochlear nucleus were processed for electron microscopy as described below.

The tissue was placed in $1 \% \mathrm{OsO}_{4}$ for $15 \mathrm{~min}$, rinsed $5 \times 5 \mathrm{~min}$ in $0.1 \mathrm{M}$ maleate buffer ( $\mathrm{pH} 5.0$ ), and stained in $1 \%$ uranyl acetate in methanol overnight $\left(5^{\circ} \mathrm{C}\right)$. The following morning, the sections were washed with $0.1 \mathrm{M}$ maleate buffer, dehydrated in increasing concentrations of methanol, infiltrated with propylene oxide and Epon, and embedded in fresh Epon between sheets of Aclar. Hardened sections were taped to microscope slides for examination with a light microscope. Relevant structures were identified and dissected from individual sections and re-embedded in BEEM capsules for electron microscopic analysis. Ultrathin sections of approximately $75 \mathrm{~nm}$ thickness were collected on Formvar-coated slotted grids, stained with $7 \%$ uranyl acetate, and viewed and photographed with a JEOL 100CX electron microscope. Because each ultrathin section represents a thin slice through any ending, only a portion of the ending appeared in any section and was referred to as an "ending profile."

\section{Data collection and analysis: light microscopy}

Bouton endings from primary auditory nerve fibers are distributed throughout the cochlear nucleus. We concentrated on those boutons in the AVCN that made contact with the cell bodies of multipolar neurons (Cant 1981; Rouiller et al. 1986). HRP-labeled boutons and associated multipolar cells were drawn at high magnification (100x oil immersion objective, NA 1.3, total magnification $2500 \times$ ) with the aid of a light microscope and drawing tube. Multipolar cells were identifiable by their polygonal somata, prominent Nissl bodies, and a pale, round, centrally placed nucleus. Nissl-stained cells were 
drawn at $2500 \times$ magnification. Drawings of cell bodies and boutons were digitized using a flatbed scanner (Umax Astra 2400S) to determine silhouette perimeter, area measurements, and calculations of somatic ending ratios (The Image Processing Tool Kit, Reindeer Games, Inc., Asheville, NC).

\section{Data collection and analysis: electron microscopy}

A total of 63 bouton endings, 34 from the 4 adult DWCs and 29 from 6 of the 10 normal-hearing cats, were analyzed by electron microscopy. Ending profiles and postsynaptic densities (PSDs) were serially reconstructed from electron micrographs. Consecutive sections (15-25) were aligned using NIH Image (v1.61), the resulting "stack" rendered into a 3dimensional image (Voxblast, VayTek Inc., Fairfield, IA), and then rotated into optimal position and viewed. The reconstructed PSDs were best appreciated when viewed en face and analyzed as they resided on the somatic surface of the multipolar cell. The area for each PSD contained within the reconstructed ending segment was determined.

The contact surface between the primary ending and postsynaptic cell was called the apposition area. Section thickness was estimated using standard interference reflection colors as the sections floated in the knife trough. The sections were silver in color, more gray than gold, and we estimate their thickness at $75 \mathrm{~nm}$. This value is consistent with our reconstructions, because 13 sections, when rotated $90^{\circ}$ and viewed en face, spanned slightly less than $1 \mu \mathrm{m}$ as determined by a calibration grid, and 14 sections slightly exceeded $1 \mu \mathrm{m}$. Means, standard deviations, and $p$ values are provided where appropriate, and group comparisons were conducted using Student's $t$ test (2-tail, unpaired), ANOVA, or Mann-Whitney $\mathrm{U}$ test (Statview v5, SAS Institute, Inc., Cary, NG). Photographic negatives were digitized (Leafscan 45), the contrast and/or exposure adjusted (if necessary) to simulate standard darkroom techniques (Adobe Photoshop, Adobe Systems Inc., San Jose, CA), and the files printed in high-resolution format (Fuji Pictrography 3000).

\section{RESULTS}

\section{Light microscopy}

Multipolar cell types. Multipolar cells are distributed throughout the AVCN, but their numbers are significantly reduced in the most anterior part of the nucleus (Cant and Morest 1979). They are lightly scattered among the spherical bushy cells in the anterior AVCN and heavily intermixed with globular bushy cells in the region surrounding the auditory

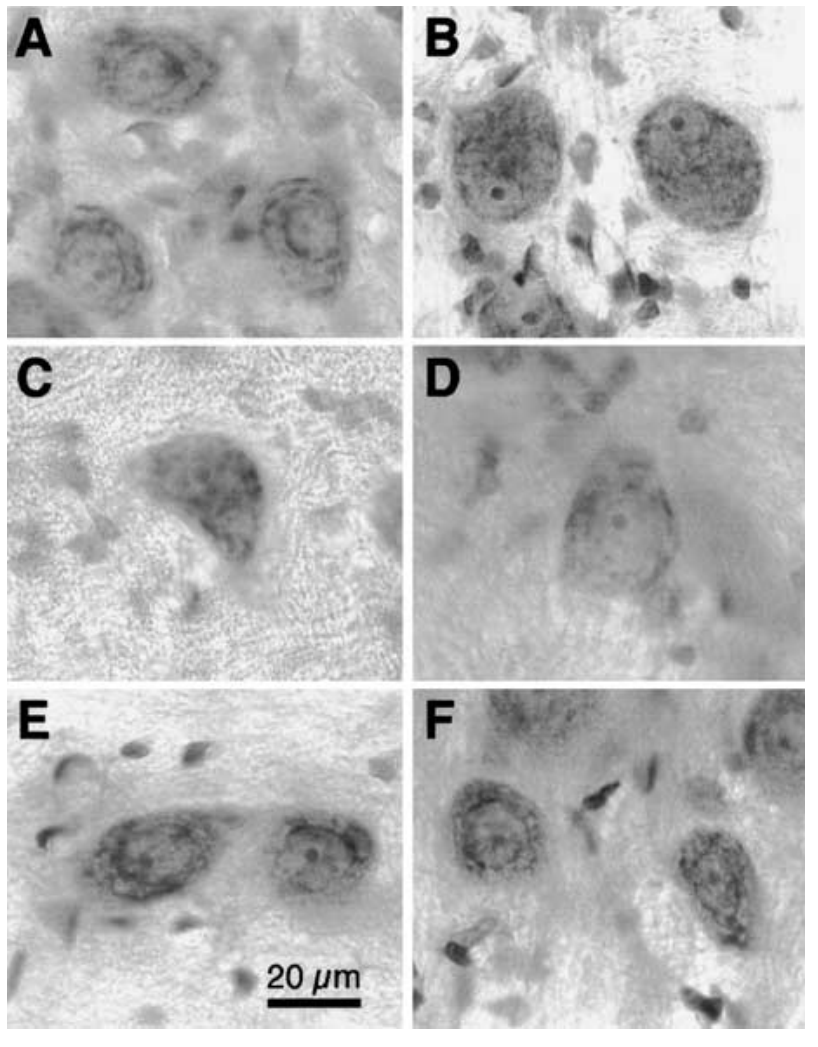

FIG. 1. Illustration of Nissl-stained cells of the cat ventral cochlear nucleus. Spherical bushy cells (A), globular bushy cells (B), and multipolar cells $(\mathbf{C}, \mathbf{D})$ from normal-hearing cats. Multipolar cells from adult DWCs $(\mathbf{E}, \mathbf{F})$.

nerve root (Tolbert and Morest, 1982a). Nevertheless, members of these cell classes can be distinguished from each other in the light microscope. Spherical bushy cells are concentrated in the anterior half of the AVCN, exhibit a pale, round, centrally placed nucleus, a distinct perinuclear cap of Nissl, and a "necklace" of cytoplasmic Nissl bodies surrounding the nucleus (Fig. 1A). Globular bushy cells are distributed in the central region of the VCN. They feature more diffuse cytoplasmic staining and a relatively small, highly eccentric nucleus that seems to bulge into the cell body (Fig. 1B). Multipolar cells, by definition, are polygonal in shape and distributed in the middle and caudal regions of the ventral cochlear nucleus (VCN). They exhibit an apparently unorganized distribution of prominent Nissl bodies and a round, centrally placed nucleus that tends to stain almost as darkly as the cytoplasm (Fig. 1C,D). Multipolar cells are clearly distinguishable from globular bushy cells in deaf white cats and are the focus of this report (Fig. 1E,F). We measured the somatic silhouette area of multipolar cells observed under the light microscope in the region of the nerve root. Analysis revealed that there was a significant difference in somatic size for multipolar cells when comparing those of hearing and deaf cats. Multipolar cells aver- 


\section{IC projecting type I}

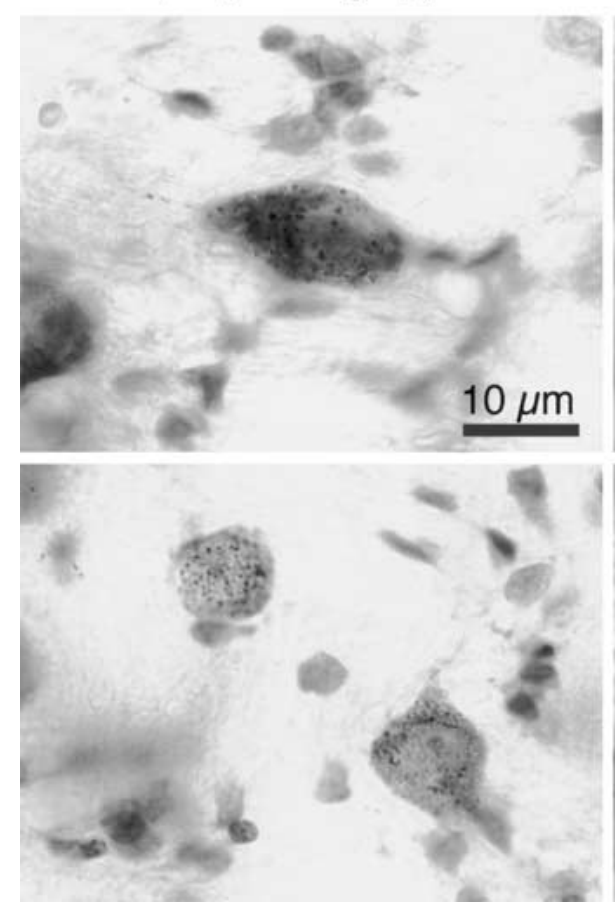

\section{CN projecting type II}
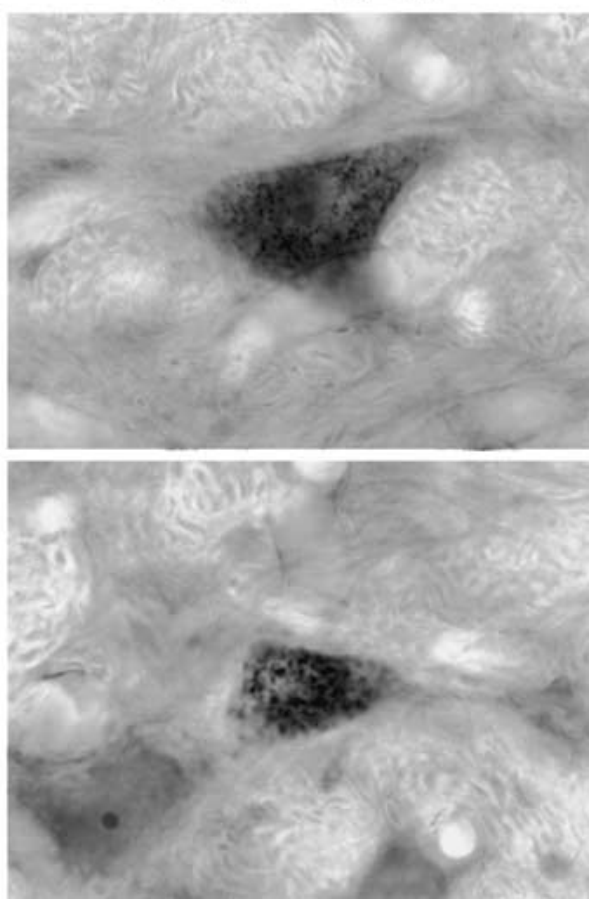

FIG. 2. Photomicrographs of the two types of multipolar cells in the ventral cochlear nucleus of normal-hearing cats. There are many type I multipolar cells, as evidenced by their strong projection to the contralateral inferior colliculus (left column). In contrast, type II multipolar cells project to the contralateral cochlear nucleus, are relatively few in number, and tend to have slightly larger cell bodies. aged $422.3 \pm 83 \mu \mathrm{m}^{2}$ ( $n=6$ cats, 50 cells per cat for hearing cats, 50 cells per cat) for hearing cats, whereas the average size from the congenitally deaf cats was $304.6 \pm 54 \mu \mathrm{m}^{2}$ ( $n=4$ cats, 50 cells per cat). This analysis revealed that multipolar cells of the DWCs are $27.9 \%$ smaller $(p<0.01)$ than those of normal-hearing cats.

Multipolar cell projections. The class of multipolar cells is composed of at least two subclasses, although they cannot be unequivocally distinguished in Nisslstained tissue with a light microscope. Type I multipolar cells project to the contralateral inferior colliculus, whereas type II multipolar cells project to the contralateral cochlear nucleus (Fig. 2). These observations are consistent with those reported previously (Cant 1982; Alibardi 1998b). HRP injections confined to one cochlear nucleus (Fig. 3A) consistently labeled large multipolar neurons in the contralateral cochlear nucleus (Fig. 3B). These retrogradely labeled commissural cells were relatively infrequent and exhibited the same regional distribution as large multipolar cells and giant cells previously described (Osen 1969; Cant and Gaston 1982). The silhouette area of type I cells was $366.0 \pm 100 \mu \mathrm{m}^{2}(n=100$ cells $)$, in contrast to that of type II cells $(571.1 \pm 228 \mu \mathrm{m}(n=27$ cells $)$. This difference in average somatic size, however, was by itself insufficient for positive identification in Nisslstained tissue because of the overlapping ranges.

Bouton endings. Individual auditory nerve fibers enter the cochlear nucleus from its ventral aspect, ascend a variable distance into the nucleus depend- ing on their site of cochlear innervation, and bifurcate into an ascending and a descending branch. Several large and medium-sized axosomatic endings, called endbulbs, characterize one type of ending emitted by auditory nerve fibers in the AVCN. Most, however, appear as small (1-3 $\mu \mathrm{m}$ in diameter) swellings that arise from thin collaterals of the main branches (Fig. 4). On occasion, boutons get as large as $5 \mu \mathrm{m}$ in diameter. Although boutons were found with or without a short series of accompanying en passant swellings, we concentrated on terminal boutons, which were closely associated with multipolar cell bodies.

HRP-labeled terminal boutons in the AVCN were drawn and measured. A minimum of 50 boutons that were in close apposition to a multipolar cell body and in the same plane of focus were drawn from each of the normal-hearing and congenitally deaf cats. The average silhouette area of boutons from normalhearing cats was $6.30 \pm 1.3 \mu \mathrm{m}^{2}$ compared with $3.22 \pm 1.8 \mu \mathrm{m}^{2}$ from deaf cats $(p<0.01)$. These light microscope data revealed that multipolar cell bodies and terminal boutons of auditory nerve fibers were smaller in congenitally deaf cats compared with those in normal-hearing cats.

\section{Electron microscopy}

Multipolar cell types. Multipolar cells contain cytoplasm that is characterized by free ribosomes, ribosomal rosettes, and many stacked arrays of rough endoplasmic 


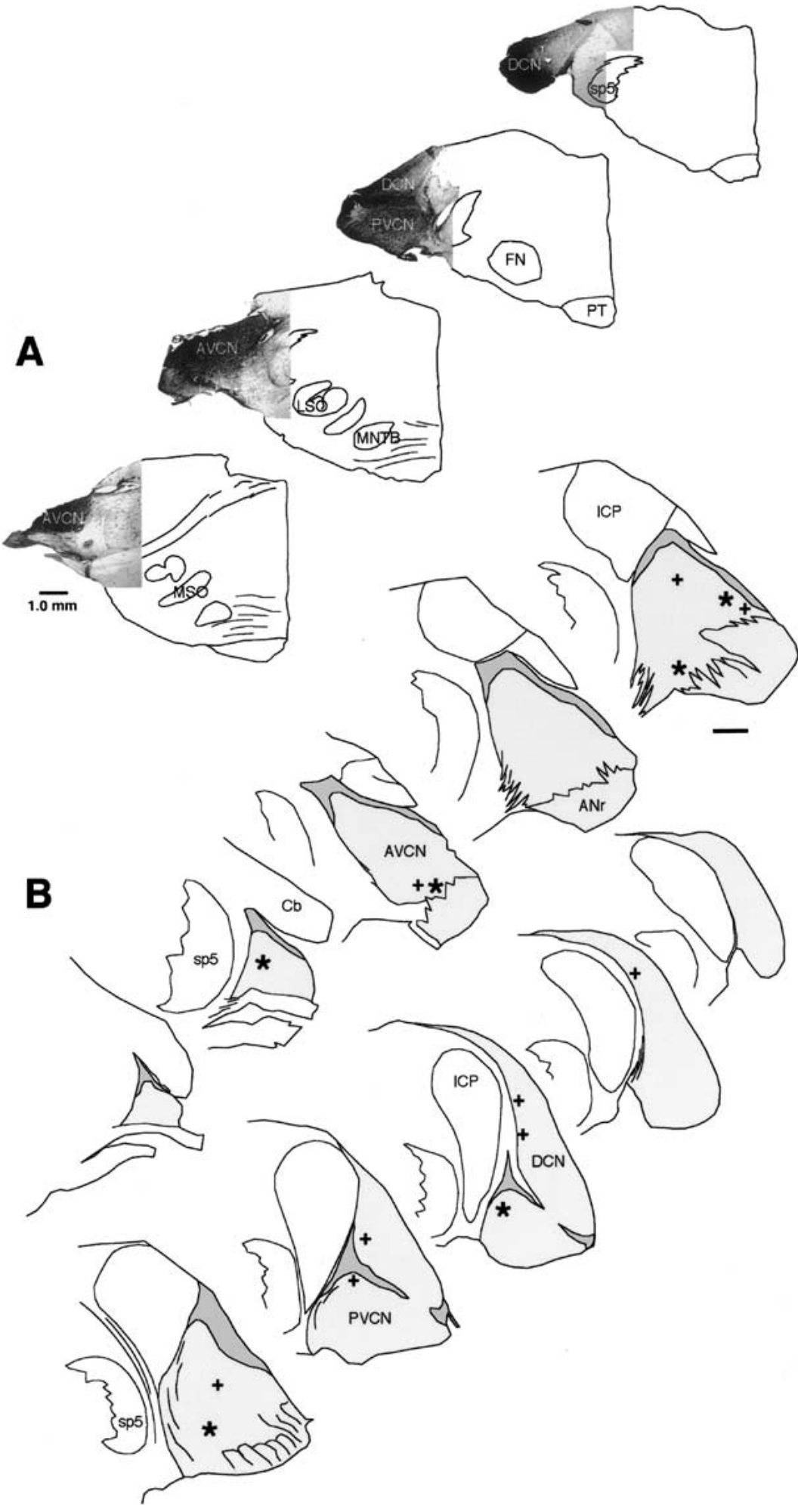

FIG. 3. A. Photomontages through the cochlear nucleus $(\mathrm{CN})$ injection site in a representative cat $(\mathrm{CN}-3)$; the remainder of the brain stem is illustrated as a camera lucida drawing. HRP reaction product is distributed throughout the VCN and in the ventral tip of the DCN but does not extend beyond the $\mathrm{CN}$ borders. B. Plot showing the distribution of HRP-labeled commissural neurons (plusses and asterisks). Asterisks indicate commissural neurons examined by electron microscopy that were identifiable as type II multipolar cells. AVCN - anteroventral cochlear nucleus; $\mathrm{Cb}-$ cerebellum; DCN - dorsal cochlear nucleus; FN facial nucleus; ICP - inferior cerebellar peduncle; LSO - lateral superior olive; MNTB - medial nucleus of the trapezoid body; MSO - medial superior olive; PT - pyramidal tract; PVCN - posteroventral cochlear nucleus; sp5 - spinal trigeminal tract; TB - trapezoid body. reticulum. Golgi complexes are also common, and the round pale nucleus occupies a relatively small volume compared with that of the cell body. The nuclear envelope is irregular and there is a thin rim of chromatin associated with the inner surface. The plasma membrane of the cell body is fairly regular in contour, with few undulations and no spinelike appendages. These cytologic criteria can differentiate multipolar cells from globular bushy cells (Tolbert and Morest 1982a,b; Tolbert et al. 1982), but do not by themselves adequately distinguish the two types of multipolar cells. 


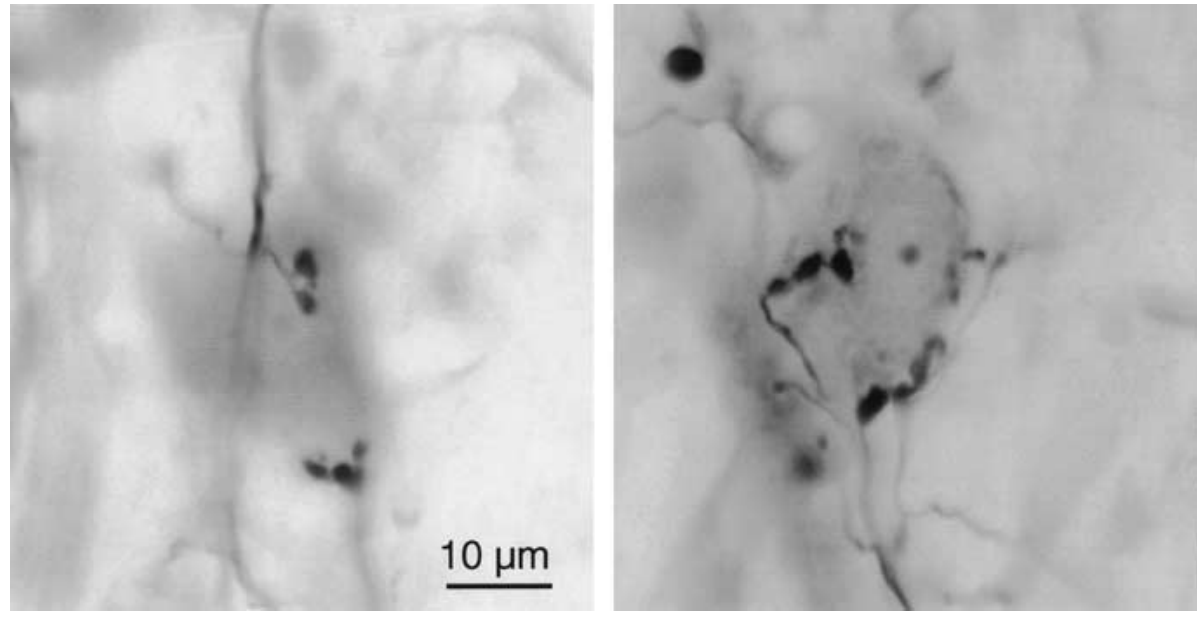

FIG. 4. Photomicrographs of HRPlabeled bouton endings in close apposition to multipolar cells in the ventral cochlear nucleus. On the basis of cell size and numbers of bouton contacts, we propose that the left panel illustrates a type I multipolar cell and the right panel illustrates a type II multipolar cell.
Criteria for distinguishing the two types of AVCN multipolar cells were clearly revealed when cells were labeled with HRP (Fig. 5). The first criterion was the difference in their projections. Type I multipolar cells were labeled by HRP injections in the contralateral inferior colliculus, as previously reported (Cant 1982; Josephson and Morest 1998). These cells tended to have small elongated cell bodies and relatively few somatic endings (Fig. 5, top). Similar to previous reports (Cant 1981), $27.8 \% \pm 8.0 \%$ of the somatic surface was covered by bouton endings ( 2 hearing cats, 10 HRP-labeled cells). These bouton endings were concentrated at the somatic poles from which primary dendrites emerge, and most contained pleomorphic or flattened synaptic vesicles. There were $0-2$ bouton endings on the cell body that contained clear, large, round synaptic vesicles. The surface that was not apposed by endings abutted myelinated axons or glial processes. Using criteria developed by the HRP labeling, we analyzed an additional 16 unlabeled type I multipolar cells from normal-hearing cats and determined that this class of cell received on average $13.1 \pm 5.1$ somatic boutons.

Commissural neurons were labeled following extracellular injections of HRP into the contralateral cochlear nucleus (Fig. 5, bottom). Associated with the HRP labeling was a somatic surface covered $75 \% \pm 10.1 \%$ by synaptic endings (4 hearing cats, 16 HRP-labeled cells). Although there was virtually no overlap in the ratio of somatic coverage with type I multipolar cells $(p<0.0001)$, terminal types contacting the commissural cell body were morphologically similar to those that contacted type I cells as well as spherical and globular bushy cells. Most of the endings contained small synaptic vesicles that were round, pleomorphic, or flattened, but approximately onethird arose from auditory nerve fibers, i.e, they contained large, clear, round vesicles, and represented, on average, $27.8 \% \pm 6.7 \%$ of the somatic endings.
The descriptive data from HRP-labeled cells provided criteria to identify unlabeled multipolar cells in normal-hearing cats and DWCs. There was no statistical difference in somatic coverage between type I multipolar cells of normal-hearing cats and DWCs or between type II multipolar cells for the same two groups. Type I multipolar cells from DWCs had an average of $16.3 \pm 6.6$ somatic endings that covered $25.8 \% \pm 5.1 \%$ of their somatic surface (4 cats, 19 cells). In contrast, type II multipolar cells from DWCs had an average of $30.8 \pm 6.9$ somatic endings that covered $68.5 \pm 15.2 \%$ of the surface ( 4 cats, 23 cells). The cell bodies of DWCs were smaller than their counterparts in normal-hearing cats $(p<0.05)$. The mean number of somatic endings was slightly but not statistically greater for DWCs and percent coverage was not different (Table 1).

Bouton endings. HRP-labeled boutons and their association with multipolar cells were readily evident in our material. Since the labeled boutons arose from fibers that were traced directly to the auditory nerve root, it is certain that they represent the primary endings of spiral ganglion neurons. We analyzed some of the lightly labeled boutons in normal-hearing cats and used their cytologic features as criteria for identifying unlabeled primary endings in normalhearing cats and DWCs. These boutons contained large, clear, round synaptic vesicles that accumulated around punctate, asymmetric membrane specializations, typical of primary endings (e.g., Ryugo et al. 1996; Tolbert and Morest 1982b). Primary endings could readily be identified, even in unlabeled tissue. In 6 normal-hearing cats, we examined 13 bouton endings through serial sections that contacted type I multipolar cells. In these same cats, we examined 16 bouton endings that contacted type II multipolar cells. These bouton endings were similar in size (Table 2), had a variable number of mitochondria, contained clear, large, round synaptic vesicles, and 

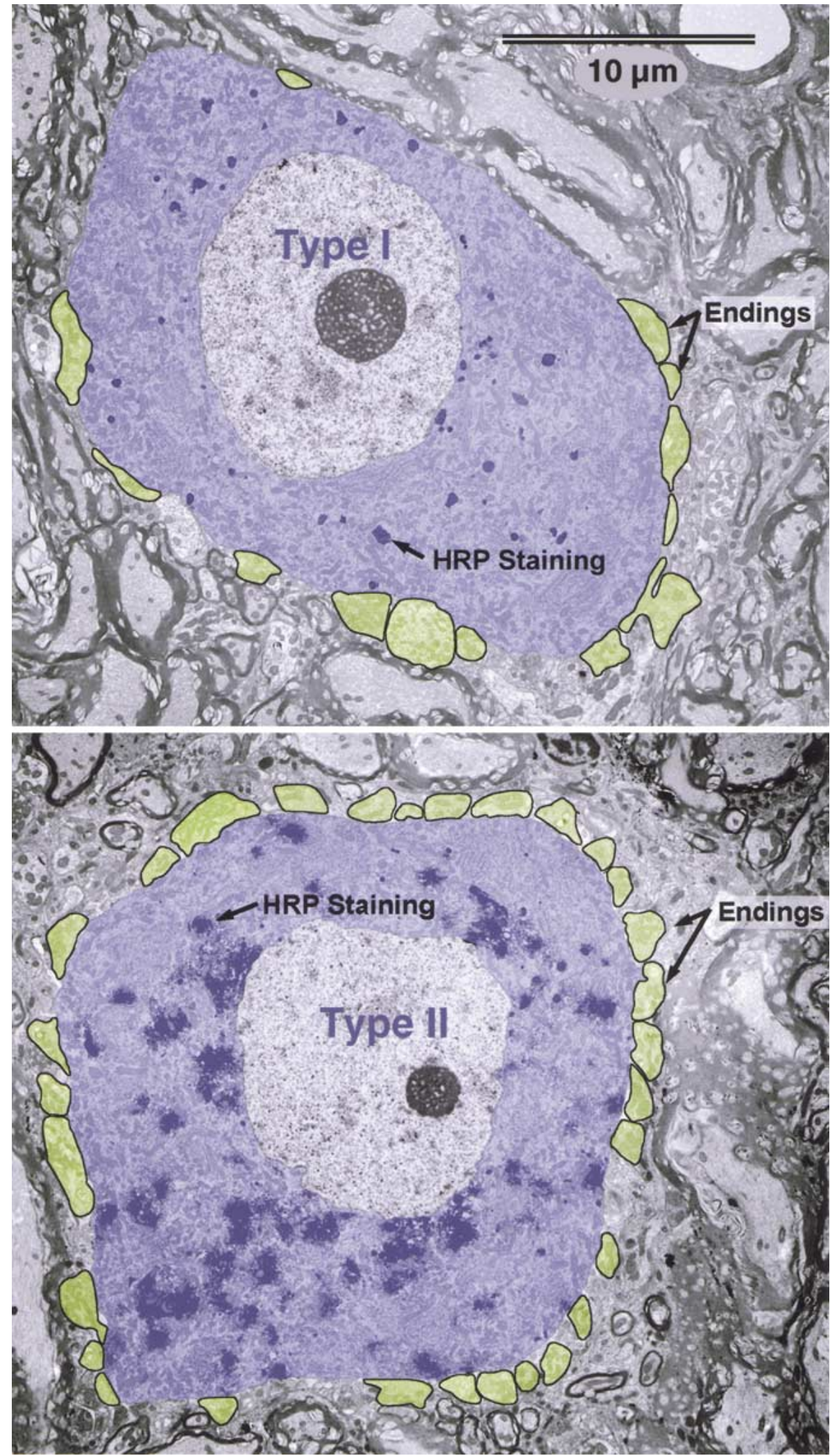

FIG. 5. Electron micrographs of representative members of the two types of multipolar cells. The top panel contains a type I multipolar cell, as revealed by the somatic HRP reaction product following a contralateral inferior colliculus injection, and the relatively sparse complement of somatic boutons. In contrast, the bottom panel contains a type II multipolar cell, identified by the somatic HRP reaction product following a contralateral cochlear nucleus injection and the high density of somatic bouton endings.

formed asymmetric membrane specializations with the postsynaptic cell bodies. The postsynaptic densities were obviously convex, and there were frequent infoldings of the presynaptic membrane that formed short channels between the bouton and somatic membrane of the multipolar cell (Fig. 6). 
TABLE 1

Cell body data $( \pm \mathrm{SD})$ (collected from electron micrographs)

\begin{tabular}{|c|c|c|c|}
\hline Multipolar cell type & Cell body area $\mu m^{2}$ & No. boutons & $\%$ coverage \\
\hline $\begin{array}{l}\text { Normal cats, type I MP cells } \\
\quad(N=6 \text { cats, } 32 \text { cells })\end{array}$ & $369.2 \pm 103.9$ & $13.1 \pm 1.2$ & $27.8 \pm 8.0$ \\
\hline $\begin{array}{l}\text { Normal cats, type II MP cells } \\
\quad(N=6 \text { cats, } 35 \text { cells })\end{array}$ & $481.6 \pm 124.8$ & $27.8 \pm 6.7$ & $75.0 \pm 10.1$ \\
\hline $\begin{array}{l}\text { DWC, type I MP cells } \\
(N=4 \text { cats, } 29 \text { cells })\end{array}$ & $305.7 \pm 60.2$ & $16.3 \pm 6.6$ & $25.8 \pm 5.1$ \\
\hline $\begin{array}{l}\text { DWC, type II MP cells } \\
(N=4 \text { cats, } 38 \text { cells })\end{array}$ & $376.5 \pm 90.4$ & $30.8 \pm 6.9$ & $68.5 \pm 15.2$ \\
\hline
\end{tabular}

ANOVA revealed that only cell size diered between hearing and deaf cats: type I cells $(p<0.05)$ and type II cells $(p<0.003)$.

TABLE 2

\begin{tabular}{|c|c|c|c|}
\hline \multicolumn{4}{|c|}{ Bouton ultrastructure data $( \pm \mathrm{SD})$} \\
\hline Multipolar cell type & Bouton area $\left(\mu m^{2}\right)$ & SVs per $\mu m^{2}$ & PSD area $\left(\mu m^{2}\right)$ \\
\hline $\begin{array}{l}\text { Normal cats, type I MP cells } \\
\quad(N=6 \text { cats, } 10 \text { cells })\end{array}$ & $\begin{aligned} 2.23 & \pm 1.8 \\
(n & =13 \text { boutons })\end{aligned}$ & $\begin{aligned} 54.8 & \pm 26 \\
(n & =13 \text { boutons })\end{aligned}$ & $\begin{aligned} 0.107 & \pm 0.09 \\
(n & =19 \text { PSDs })\end{aligned}$ \\
\hline $\begin{array}{l}\text { Normal cats, type II MP cells } \\
\quad(N=6 \text { cats, } 16 \text { cells })\end{array}$ & $\begin{aligned} 2.87 & \pm 1.5 \\
(n & =16 \text { boutons })\end{aligned}$ & $\begin{aligned} 81.5 & \pm 40 \\
(n & =16 \text { boutons })\end{aligned}$ & $\begin{aligned} 0.138 & \pm 0.09 \\
(n & =28 \text { PSDs })\end{aligned}$ \\
\hline $\begin{array}{l}\text { DWCs, type I MP cells } \\
\qquad(N=4 \text { cats, } 14 \text { cells })\end{array}$ & $\begin{aligned} 2.83 & \pm 1.6 \\
(n & =15 \text { boutons })\end{aligned}$ & $\begin{aligned} 73.5 & \pm 27 \\
(n & =15 \text { boutons })\end{aligned}$ & $\begin{aligned} 0.087 & \pm 0.10 \\
(n & =54 \text { PSDs })\end{aligned}$ \\
\hline $\begin{array}{l}\text { DWCs, type II MP cells } \\
(N=4 \text { cats, } 15 \text { cells })\end{array}$ & $\begin{aligned} 1.94 & \pm 1.1 \\
(n & =19 \text { boutons })\end{aligned}$ & $\begin{aligned} 45.9 & \pm 23 \\
(n & =19 \text { boutons })\end{aligned}$ & $\begin{aligned} 0.184 & \pm 0.30 \\
(n & =73 \text { PSDs })\end{aligned}$ \\
\hline
\end{tabular}

ANOVA revealed that there were no significant dierences between groups.

We also examined 15 bouton endings contacting type I multipolar cell somata and 19 bouton endings contacting type II multipolar cell somata from 4 DWCs and compared their size and cytologic features to those of normal cats. Specifically, we reconstructed individual PSDs through serial sections using computer software and then rotated them to be viewed en face (Fig. 7). We found no statistically significant size differences between PSDs associated with bouton endings contacting the different multipolar cells in the hearing and deaf cats (Table 2). This lack of change in PSD size was observed for the DWC multipolar cells and could be directly contrasted to the striking PSD hypertrophy in spherical and globular bushy cells in the same animals (Ryugo et al. 1997, 1998; Redd et al. 2000). The complement of synaptic vesicles in boutons varied widely from ending to ending, and there was no statistical difference in synaptic vesicle density between hearing and deaf cats. We did, however, note that the channels between the pre- and postsynaptic membranes mostly disappeared in the DWCs (Figs. 6 and 7).

\section{DISCUSSION}

In this report we describe the cytology of primary bouton endings that synapse on type I and type II multipolar cells in the AVCN of cats. Type I multipolar cells receive relatively few axosomatic terminals (approximately 15), whereas type II multipolar cells receive more (roughly 30 ), findings that are in general agreement with Cant (1981). We confirmed that type I multipolar cells project to the contralateral inferior colliculus (Cant 1982; Alibardi 1998a) and that type II multipolar cells project to the contralateral cochlear nucleus (Alibardi 1998b). Despite the different postsynaptic targets, the bouton endings from auditory nerve fibers were essentially identical in synaptic structure. Finally, we compared the synaptic morphology of these bouton endings in normalhearing cats with those of congenitally deaf white cats and observed that there were no significant changes in the most obvious synaptic features (e.g., PSD size, synaptic vesicle density) although there was a dramatic reduction in intercellular channels in DWCs (Fig. 8). The lack of a detectable change in stellate cell PSDs is in stark contrast to prominent changes in spherical and globular bushy cells examined in the same cats (Ryugo et al. 1997, 1998; Redd et al. 2000).

It is also noteworthy that cell bodies in the deaf animals were smaller in size compared with those in normal animals, and yet the percent of somatic coverage did not change. Because we concentrated our analysis on primary endings and not on those 

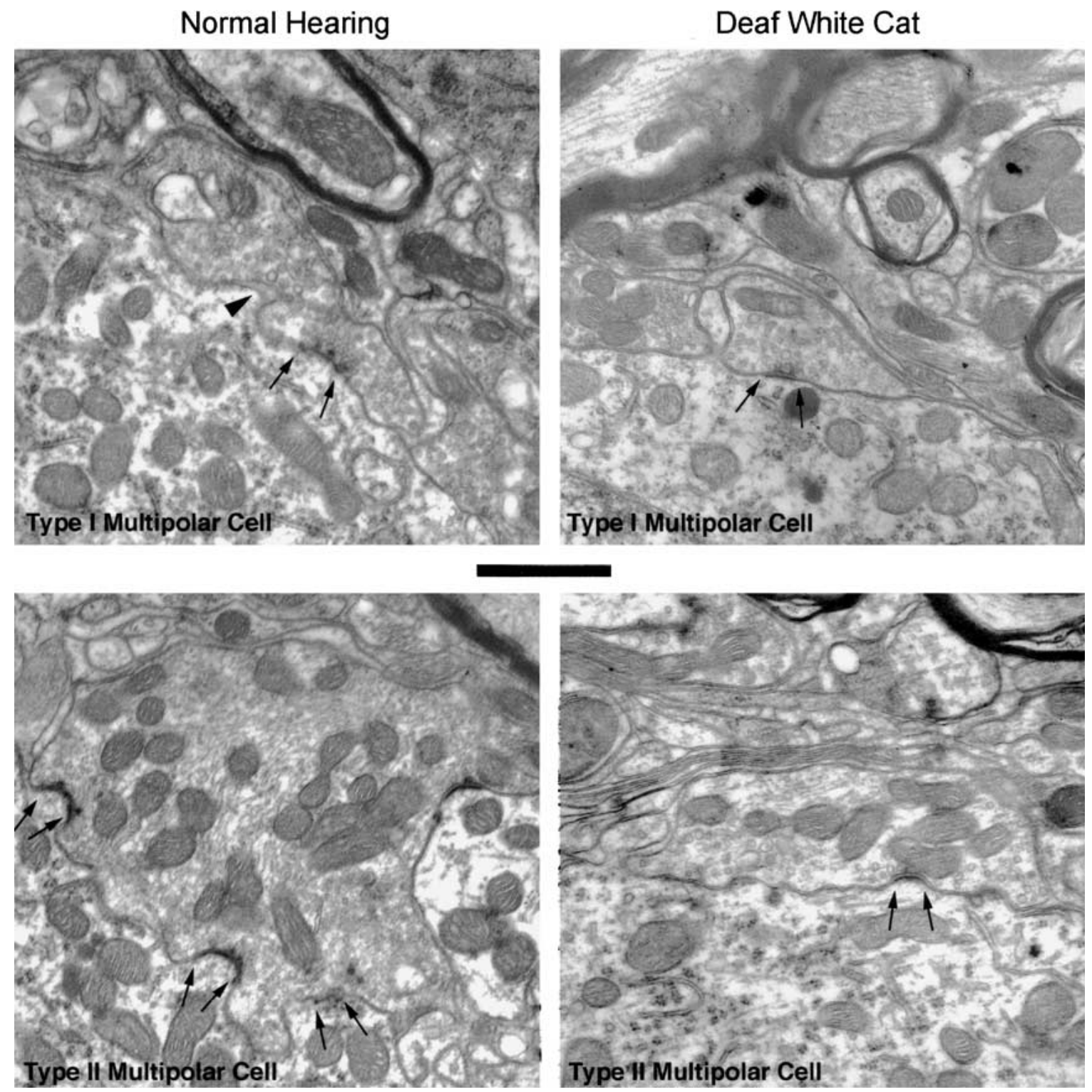

FIG. 6. Electron micrographs of typical bouton synapses upon the two types of multipolar cells, comparing normal-Hearing and congenitally deaf cats. In normal-hearing cats, boutons of auditory nerve fibers exhibited characteristic structural features, including synapses and intercellular channels (arrowhead). The synapse (flanked by

with pleomorphic, flat, or small round vesicles, we do not know how nonprimary endings respond to deafness. Although primary endings most likely became smaller, nonprimary endings could have increased in size. Finally, there was a slight but nonsignificant increase in the number of somatic endings on the multipolar cells of the DWCs (Table 1). A possible increase in nonprimary bouton size and a trend for more boutons to contact multipolar cells in the DWCs might be sufficient to help maintain somatic coverage percentages despite cell body shrinkage.

arrows) displayed clear round vesicles, asymmetric membrane thickenings, and convex postsynaptic densities. Boutons of DWCs were similar in appearance, although they lacked the intercellular channels.

\section{Type II multipolar cell projections}

Although the axonal projections of type I multipolar cells have been known for some time, the axonal projections of type II multipolar cells had not been known for cats (Cant 1981, 1982; Smith and Rhode 1989 ) and only recently were reported for rats (Alibardi 1998b). We demonstrated that the type II multipolar cells project to the contralateral cochlear nucleus in cats. The distinction between type I and type II multipolar cells can now be made on the basis of axonal projections as well as electron microscopic 


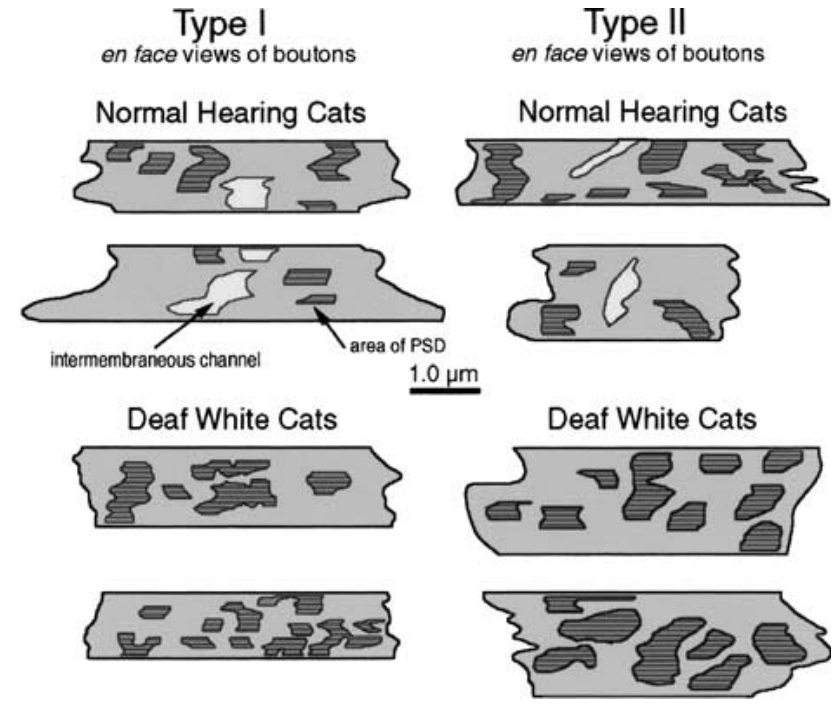

FIG. 7. En face views of the reconstructed somatic surface of multipolar cells lying postsynaptic to the bouton endings. The PSDs from normal-hearing cats (top) are typically small (dark gray with horizontal lines) and are associated with short intercellular channels (light gray). Bouton endings from congenitally deaf white cats (bottom) reveal PSDs of similar size and shape as those of normalhearing cats but lack the channels. The horizontal lines in the PSDs indicate each ultrathin section involved in the reconstruction.

criteria involving the number of somatic endings. Light microscopic data in rats have shown that a small number of relatively large multipolar neurons project to the contralateral cochlear nucleus and the ipsilateral dorsal cochlear nucleus and that they are immunostained with antibodies directed against glycine (Wenthold 1987; Doucet and Ryugo 1997; Doucet et al. 1999). On the basis of somatic size and shape, axonal projections, and glycine immunoreactivity, we hypothesize that cat type I multipolar cells represent the rat planar neurons and that cat type II multipolar cells represent the rat radiate cells.

\section{Bouton size and shape}

Bouton endings arise from collateral branches of auditory nerve fibers and are closely apposed to a neuronal cell body or distributed within the neuropil. These endings vary from round to oval in shape but are grouped together by virtue of their profile being continuously convex. They are the smallest terminals in the AVCN and they are even smaller in congenitally deaf cats. Why this difference was measurable using a light microscope but not an electron microscope is unclear. The light microscopic difference was unambiguous, so there may be some kind of sampling bias in the ultrastructural data. Because we selected those boutons with salient PSDs for analysis, we biased ourselves in choosing only the largest boutons for electron microscopic analysis. Such a selection bias, especially with the relatively small sample, could serve to reduce size differences.

\section{Postsynaptic densities}

In congenitally DWCs older than 6 months of age, there is a hypertrophy of PSDs in both spherical and globular bushy cells, suggesting an upregulation of transmitter receptors (Ryugo et al. 1997; Redd et al. 2000). This growth of the PSDs, where the glutamate ionotropic transmitter receptors are localized (Nusser et al. 1994; Wang et al. 1998), may reflect a compensatory response to reduced transmitter release. With diminished or absent spike activity, there may be a proliferation of receptors so that when transmitter is occasionally released, the postsynaptic cell is optimized for responding. The PSD hypertrophy of spherical bushy cells was considerable in spherical bushy cells, moderate in globular bushy cells, and absent in multipolar cells.

The question emerges as to whether PSD hypertrophy in response to deafness is related to average levels of spike activity in the different cell types when comparing normal cats to DWCs. Certainly, all evoked activity in DWCs is abolished, and spontaneous activity in auditory nerve fibers is also severely reduced (Ryugo et al. 1998). But what about spontaneous activity in cochlear nucleus neurons of normalhearing cats? If deafness-induced hypertrophy of PSDs is due to a sharp contrast in levels of activity for the separate conditions, then cells with higher spartaneous rates (SR) would suffer proportionally larger activity reductions compared with cells with lower SR.

Consequently, active cells might be more prone to exhibit effects of deafness. Spherical bushy cells, the structural correlate for primaray-like units, and globular bushy cells, the structural correlate for primarylike units with notch (e.g., Bourk 1976; Rhode et al. 1983; Spirou et al. 1990; Smith et al. 1991, 1993) exhibit relatively high levels of spontaneous activity (e.g., on average $>30 \mathrm{~s} / \mathrm{s}$, Blackburn and Sachs 1989) and they exhibit deafness-induced PSD hypertrophy. By contrast, type I multipolar cells, the structural correlate of sustained choppers, and type II multipolar cells, the structural correlate of onset choppers, exhibit low levels of SR (e.g., on average $<7$ spikes/s, Bourk 1976; Rhode and Smith 1986; Smith and Rhode 1989; Blackburn and Sachs 1989) and manifest no hypertrophy of their PSDs. The multipolar cells would experience relatively less activity loss in the case of deafness and thus might exhibit a correspondingly smaller PSD reaction. Although simplistic in concept, it is tempting to propose a role for the magnitude of change in spike activity for the differential upregulation of PSDs in the separate cell classes. 


\section{Type I Multipolar Cells}

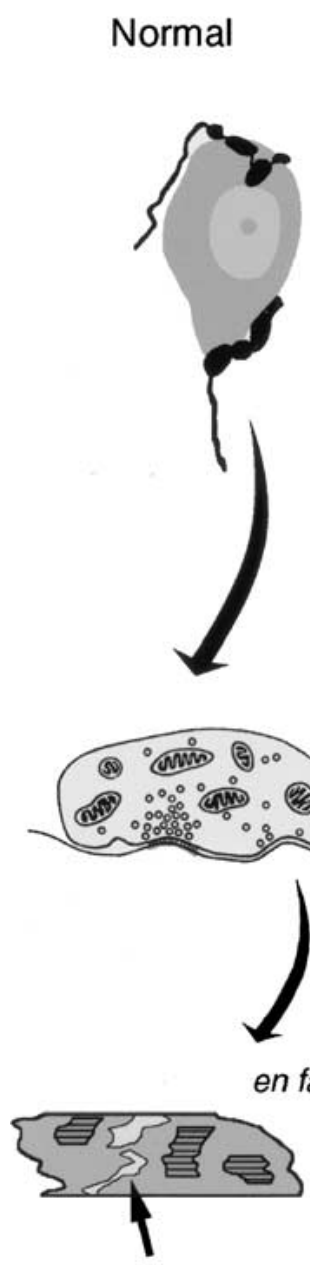

Intermembraneous channel

Deaf

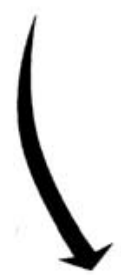

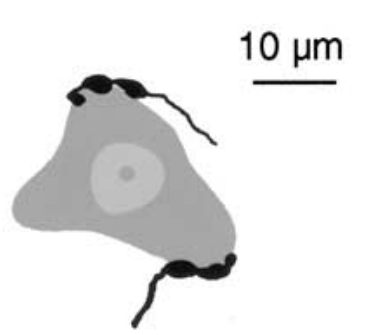

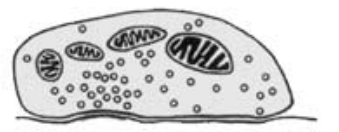

Intermemb
$0.5 \mu \mathrm{m}$
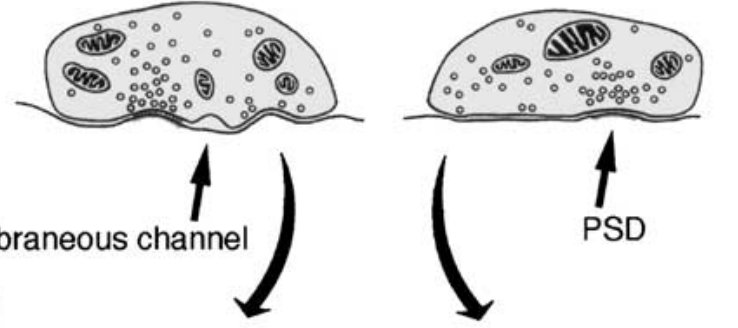

en face view of PSDs

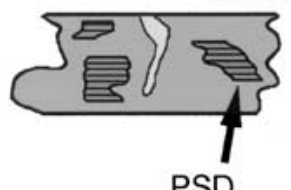

PSD

FIG. 8. Summary diagram comparing the relationship of bouton endings with the two types of multipolar cell in normal-hearing and congenitally deaf cats. There was no detectable structural difference other than a loss of intercellular channels in DWCs.

\section{Cell body size}

There is a difference in the amount of primary somatic endings contacting type I and type II multipolar cells. In general, 0-2 boutons with clear, large, round synaptic vesicles (typical of auditory nerve endings) were found apposed type I multipolar cells. In contrast, 3-10 boutons from auditory nerve fibers were found against type II multipolar cells. This relative difference in "drive" from the auditory nerve might help explain why type I multipolar cells were smaller by $20.9 \%$ compared with type II multipolar cells that were smaller by $27.9 \%$.

\section{Synaptic vesicles}

While synaptic vesicle density might be related to the efficacy of neurotransmission, there was wide variability in its value within and across the different primary ending types (e.g., endbulbs, modified endbulbs, and boutons) in normal-hearing and congenitally deaf cats (Ryugo et al. 1997, 1998; Redd et al. 2000 ). It may be that analysis of synaptic vesicles is confounded by mixing "releasable" pools of synaptic vesicles with "reserve" pools of vesicles, although all synaptic vesicles in primary endings diminished markedly in number in the old (6.5 year old) DWC.

\section{Extracellular space}

In normal-hearing cats, a network of intercellular channels is evident between the presynaptic ending and the postsynaptic cell body. These channels of extracellular space are formed by shallow infoldings of the presynaptic membrane and they are present in both large and small primary endings. In the endbulbs of Held, this network is especially striking because it is reliably associated with synapses and, since endbulbs 
have from 500 to 1500 release sites (Ryugo et al. 1996), the network is rather extensive. In congenitally deaf cats, there is a conspicuous loss of these channels of extracellular space. This loss seems due to a flattening of the presynaptic membrane against the somata.

What is the function of these intercellular channels? One possibility is that they are related to transmitter inactivation. Glutamate is thought to be the main neurotransmitter for the cochlear nerve (Wenthold et al. 1993; Hackney et al. 1996). Transmitter released from auditory nerve endings must be rapidly removed from the synaptic cleft so that the postsynaptic cell is prepared for the next transmission. The removal and inactivation of neurotransmitter is presumably performed by a highly efficient system of uptake and transporter molecules that surround glutamatergic synapses (Bergles et al. 1997, 1999; Diamond and Jahr 1997). Might transporter molecules be distributed along these intercellular channels? When there is a loss of activity in auditory nerve fibers in deafness (Ryugo et al. 1998), the need for synaptic readiness is reduced and the system of transporters becomes obsolete. The presence of transporter molecules lining these intercellular channels might provide useful insights into synaptic function.

\section{Summary}

These data contribute to the idea that deafness does not affect primary synapses in an identical way because spherical and globular bushy cells with their associated endbulbs manifest their own set of abnormalities that are distinct from multipolar cells (Ryugo et al. 1997; Redd et al. 2000). It is not surprising that different endings and their target neurons exhibit differential sensitivities to congenital deafness. After all, the separate neuron classes differ across many other biological parameters, including spike discharge levels, temporal response patterns, and thresholds to activation (Pfeiffer 1966; Young et al. 1988; Blackburn and Sachs 1989); composition of ion channels and transmitter receptors (Manis and Marx 1991; Oertel 1991; Rubio and Wenthold 1997); dendritic morphology (Brawer et al. 1974; Hackney et al. 1990); sources and types of inputs (Cant and Morest 1978; Lorente de Nó 1981; Spangler et al. 1987; Schofield and Cant 1996); and output projections (Ryugo et al. 1981; Warr 1982; Doucet and Ryugo 1997). We observed that the severity of some abnormalities in cochlear nucleus neurons did not change markedly with age. For example, hypertrophy of the PSDs or loss of intercellular channels appeared by 6 months of age but did not become more severe out to 6 years of age. In contrast, there was a general loss of synaptic vesicles in endings of the older deaf animals. It seems clear that the rich variety of deafness- induced abnormalities compromise processing throughout the central auditory system.

\section{ACKNOWLEDGMENTS}

This work was supported by NIH/NIDCD grants DC00232 and DC00027, a resident research grant from the American Academy of Otolaryngology, and a gift from Advanced Bionics Corp. Thanks go to Liana Rose and Alison Wright for technical assistance and helpful comments on the manuscript and to our two anonymous reviewers.

\section{REFERENCES}

ALIBARDI L. Ultrastructural and immunocytochemical characterization of neurons in the rat ventral cochlear nucleus projecting to the inferior colliculus. Ann. Anat. 180:415-426, 1998a.

AliBARDI L. Ultrastructural and immunocytochemical characterization of commissural neurons in the ventral cochlear nucleus of the rat. Ann. Anat. 180:427-438, 1998b.

Bergles DE, Diamond JS, Jahr CE. Clearance of glutamate inside the synapse and beyond. Curr. Opin. Neurobiol. 9:293-298, 1999.

Bergles DE, Dzubay JA, Jahr CE. Glutamate transporter currents in Bergmann glial cells follow the time course of extrasynaptic glutamate. Proc. Natl. Acad. Sci. U.S.A. 94:14821-14825, 1997.

Bergsma D, Brown K. White fur, blue eyes, and deafness in the domestic cat. J. Hered. 62:171-185, 1971.

Blackburn CC, SACHS MB. Classification of unit types in the anteroventral cochlear nucleus: post-stimulus time histograms and regularity analysis. J. Neurophysiol. 62:1303-1329, 1989.

Blackstad TW, Osen KK, Mugnaini E. Pyramidal neurones of the dorsal cochlear nucleus: A Golgi and computer reconstruction study in cat. J. Neurosci. 13:827-854, 1984.

Bosher S, Hallpike C. Observations on the histological features, development and pathogenesis of the inner ear degeneration of the deaf white cat. Proc. R. Soc. Lond. B Biol. Sci. 162:147-170, 1965.

Boudreau JC, TSuchitani C. Binaural interaction in the cat superior olive S segment. J. Neurophysiol. 31:442-454, 1968.

Bourk TR (1976) Electrical Responces of Neural Units in the Anterovential Cochlear Nucleus of the cat. Ph.D. Dissertation, Massachusetts Institute of Technology, Cambridge.

BraWer JR, Morest DK, Kane EC. The neuronal architecture of the cochlear nucleus of the cat. J. Comp. Neurol. 155:251-300, 1974.

Brown KS, Bergsma DR, Barrow MV. Animal models of pigment and hearing abnormalities in man. Birth Defects Orig. Artic. Ser. 7:102-109, 1971.

CANT NB. The fine structure of two types of stellate cells in the anterior division of the anteroventral cochlear nucleus of the cat. Neuroscience 6:2643-2655, 1981.

CANT, NB. Identification of cell types in the anteroventral cochlear nucleus that project to the inferior colliculus. Neurosci. Lett. 32:241-246, 1982.

Cant NB, Gaston KC. Pathways connecting the right and left cochlear nuclei. J. Comp. Neurol. 212:313-326, 1982.

Cant NB, Morest DK. Axons from non-cochlear sources in the anteroventral cochlear nucleus of the cat. A study with the rapid Golgi method. Neuroscience 3:1003-1029, 1978.

Cant NB, Morest DK. Organization of the neurons in the anterior division of the anteroventral cochlear nucleus of the cat. Light-microscopic observations. Neuroscience 4:1909-1923, 1979. 
Diamond JS, Jahr CE. Transporters buffer synaptically released glutamate on a submillisecond time scale. J. Neurosci. 17:46724687, 1997.

Doucet JR, Ross AT, Gillespie MB, Ryugo DK. Glycine immunoreactivity of multipolar neurons in the ventral cochlear nucleus which project to the dorsal cochlear nucleus. J. Comp. Neurol. 408:515-531, 1999.

DoucET JR, Ryugo DK. Projections from the ventral cochlear nucleus to the dorsal cochlear nucleus in rats. J. Comp. Neurol. 385:245-264, 1997.

Hackney CM, Osen KK, Kolston J. Anatomy of the cochlear nuclear complex of guinea pig. Anat. Embryol. 182:123-149, 1990.

Hackney CM, Osen KK, Ottersen OP, Storm-Mathisen J, Manjaly G. Immunocytochemical evidence that glutamate is a neurotransmitter in the cochlear nerve: A quantitative study in the guinea-pig anteroventral cochlear nucleus. Eur. J. Neurosci. 8:79-91, 1996.

Hardie NA, Martsi-McClintoc A, Aitkin LM, Shepherd RK. Neonatal sensorineural hearing loss affects synaptic density in the auditory midbrain. NeuroReport 9:2019-2022, 1998.

Hardie NA, Shepherd RK. Sensorineural hearing loss during development: morphological and physiological response of the cochlea and auditory brainstem. Hear. Res. 128:147-165, 1999.

Heid S, Jähn-Siebert TK, Klinke R, Hartmann R, Langner G. Afferent projection pattern in the auditory brainstem in normal cats and congenitally deaf white cats. Hear. Res. 110:191-199, 1997.

IRVINE DRF. The auditory brainstem. A review of the structure and function of auditory brainstem processing mechanisms. New York, Springer-Verlag. 1986.

IRvine DRF. Physiology of the auditory brainstem. In: Popper AN, Fay RR, (eds) The mammalian Auditory Pathway: Neurophysiology. New York, Springer-Verlag, pp 153-231, 1992.

JosephSOn EM, MoREst DK. A quantitative profile of the synapses on the stellate cell body and axon in the cochlear nucleus of the chinchilla. J. Neurocytol. 27:841-864, 1998.

KeLley MS, LuRIE DL, Rubel EW. Rapid regulation of cytoskeletal proteins and their mRNAs following afferent deprivation in the avian cochlear nucleus. J. Comp. Neurol. 389:469-483, 1997.

LARSEN SA, Kirchoff TM. Anatomical evidence of plasticity in the cochlear nuclei of deaf white cats. Exp. Neurol. 115:151-157, 1992.

Lorente de Nó R. The Primary Acoustic Nuclei. New York, Raven Press. 1981.

Lustig LR, Leake PA, SNyder RL, Rebscher SJ. Changes in the cat cochlear nucleus following neonatal deafening and chronic intracochlear electrical stimulation. Hear. Res. 74:29-37, 1994.

MAIR IW. Hereditary deafness in the white cat. Acta Otolaryngol. 314:1-48, 1973

Manis PB, Marx SO. Outward currents in isolated ventral cochlear nucleus neurons. J. Neurosci. 11:2865-2880, 1991.

Marianowski R, Lia WH, Van Den Abbeele T, Fillit P, Herman P, Frachet B, Huy PT. Expression of NMDA, AMPA, and GABA(A) receptor subunit mRNAs in the rat auditory brainstem. I. Influence of early auditory deprivation. Hear. Res. 150:1-11, 2000.

Moore DR, Kitzes LM. Projections from the cochlear nucleus to the inferior colliculus in normal and neonatally cochlea-ablated gerbils. J. Comp. Neurol. 240:180-195, 1985.

Niparko JK, Kirk KI, Mellon NK, Robbins AM, Tucci DF, Wilson BS (2000) Cochlear Implants: Principles and Practices. Lippincott Williams \& Wilkis, Philadelphia.

Nordeen KW, Killackey HP, Kitzes LM. Ascending projections to the inferior colliculus following unilateral cochlear ablation in the neonatal gerbil, Meriones unguiculatus. J. Comp. Neurol. 214:144-153, 1983.
Nusser Z, Mulvihill E, Streit P, Somogri P. Subsynaptic segregation of metabotropic and ionotropic glutamate receptors as revealed by immunogold localization. Neuroscience 61: 421-427, 1994.

Oertel D. The role of intrinsic neuronal properties in the encoding of auditory information in the cochlear nuclei. Curr. Opin. Neurobiol. 1:221-228, 1991.

OsEN KK. Cytoarchitecture of the cochlear nuclei in the cat. J. Camp. Neurol. 136:453-482, 1969

PFeIffer RR. Classification of response patterns of spike discharges for units in the cochlear nucleus: Tone burst stimulation. Exp. Brain Res. 1:220-235, 1966.

Powell TPS, Erulkar SD. Transneuronal cell degeneration in the auditory relay nuclei if the cat. J. Anat. Lond. 96:249-268, 1962.

Pujol R, Rebillard M, Rebillard G. Primary neural disorders in the deaf white cat cochlea. Acta Otolaryngol. 83:59-64, 1977.

Rawitz B. Gehörorgan und gehirn eines weissen Hundes mit blauen Augen. Morphol. Arbeit. 6:545-554, 1896.

Rebillard M, Rebillard G, Pujol R. Variability of the hereditary deafness in the white cat. I. Physiology. Hear. Res. 5:179-181, 1981.

Redd EE, Pongstaporn T, Ryugo DK. The effects of congenital deafness on auditory nerve synapses and globular bushy cells in cats. Hear. Res. 147:160-174, 2000.

Rhode WS, Oertel D, Smith PH. Physiological response properties of cells labeled intracellularly with horseradish peroxidase in cat ventral cochlear nucleus. J. Comp. Neurol. 213:448-463, 1983.

Rhode WS, Smith PH. Encoding timing and intensity in the ventral cochlear nucleus of the cat. J. Neurophysiol. 56:261-286, 1986.

Rouiller EM, Cronin-Schreiber R, Fekete DM, Ryugo DK. The central projections of intracellularly labeled auditory nerve fibers in cats: An analysis of terminal morphology. J. Comp. Neurol. 249:261-278, 1986.

Rubel EW, PARKS TN. Organization and development of the avian brain-stem auditory system. In: Edelman GM, Gall WE, Cowan WM (eds) Auditory Function: Neurobiological Bases of Hearing. New York, John Wiley \& Sons, pp 3-92, 1988.

Rubio ME, Wenthold JR. Glutamate receptors are selectively targeted to postsynaptic sites in neurons. Neuron 18:939-950, 1997.

Russell FA, MOORE DR. Afferent reorganization within the superior olivary complex of the gerbil: Development and induction by neonatal, unilateral cochlear removal. J. Comp. Neurol. 352: 607-625, 1995

Russell FA, MOoRe DR. Effects of unilateral cochlear removal on dendrites in the gerbil medial superior olivary nucleus. Eur. J. Neurosci. 11:1379-1390, 1999.

Ryugo DK, Limb CJ, Redd EE. Synaptic plasticity: The impact of the environment on the brain as it relates to cochlear implants. In: Niparko JK, Kirk KI, Mellon NK, Robbins AM, Tucci DL, Wilson BS (eds) Cochlear Implants: Principles and Practices. Lippincott Williams \& Wilkins, Philadelphia, pp 33-56, 2000.

Ryugo DK, Pongstagporn T, Huchton DM, Niparco JK. Ultrastructural analysis of primary endings in deaf white cats: Morphologic alterations in endbulbs of Held. J. Comp. Neurol. 385:230-244, 1997.

Ryugo DK, Rosenbaum BT, Kim PJ, Niparko JK, SaAda AA. Single unit recordings in the auditory nerve of congenitally deaf white cats: morphological correlates in the cochlea and cochlear nucleus. J. Comp. Neurol. 397:532-548, 1998.

Ryugo DK, Willard FH, Fekete DM. Differential afferent projections to the inferior colliculus from the cochlear nucleus in the albino mouse. Brain Res. 210:342-349, 1981.

Ryugo DK, Wu MM, Pongstaporn T. Activity-related features of synapse morphology: A study of endbulbs of Held. J. Comp. Neurol. 365:141-158, 1996. 
SAAda AA, Niparko JK, Ryugo DK. Morphological changes in the cochlear nucleus of congenitally deaf white cats. Brain Res. 736:315-328, 1996.

SCHOFIELd BR, CANT NB. Origins and targets of commissural connections between the cochlear nuclei in guinea pigs. J. Comp. Neurol. 375:128-146, 1996.

SCHWARTZ IR, Higa JF. Correlated studies of the ear and brainstem in the deaf white cat: Changes in the spiral ganglion and the medial superior olivary nucleus. Acta Otolaryngol. 93:9-18, 1982.

SIE KC, RubEL EW. Rapid changes in protein synthesis and cell size in the cochlear nucleus following eighth nerve activity blockade or cochlea ablation. J. Comp. Neurol. 320:501-508, 1992.

Sininger YS, Doyle KJ, Moore JK. The case for early identification of hearing loss in children. Auditory system development, experimental auditory deprivation, and development of speech perception and hearing. Pediatr. Clin. North Am. 46:1-14, 1999.

Smith PH, Joris PX, Banks MI, Yin TJ. Responses of cochlear nucleus cells and projections of their axons. In: Merchán MA, Juiz JM, Godfrey DA, Mugnaini E (eds) The Mammalian Cochlear Nuclei: Organization and Function. New York, Plenum Press, pp 349-371, 1993.

Smith PH, Joris PX, Carney LH, Yin TC. Projections of physiologically characterized globular bushy cell axons from the cochlear nucleus of the cat. J. Comp. Neurol. 304:387-407, 1991.

Sмiтh PH, Rhode WS. Structural and functional properties distinguish two types of multipolar cells in the ventral cochlear nucleus. J. Comp. Neurol. 282:595-616. 1989.

Sokolich WG. Improved acoustic system for auditory research. J. Acoust. Soc. Am. Suppl. 62:S12, 1977.

Spangler KM, Cant NB, Henkel CK, Farley GR, Warr WB. Descending projections from the superior olivary complex to the cochlear nucleus of the cat. J. Comp. Neurol. 259:452-465, 1987.

Spirou GA, Brownell WE, Zidanic M. Recordings from cat trapezoid body and HRP labeling of globular bushy cell axons. J. Neurophysiol. 63:1169-1190, 1990.

Tolbert LP, Morest DK. The neuronal architecture of the anteroventral cochlear nucleus of the cat in the region of the cochlear nerve root: Golgi and Nissl methods. Neuroscience. 7:3013-3030, 1982a.

Tolbert LP, Morest DK. The neuronal architecture of the anteroventral cochlear nucleus of the cat in the region of the cochlear nerve root: Electron microscopy. Neuroscience 7:3053-3067, 1982b.
Tolbert LP, Morest DK, Yurgelun-Todd DA. The neuronal architecture of the anteroventral cochlear nucleus of the cat in the region of the cochlear nerve root: Horseradish peroxidase labelling of identified cell types. Neuroscience 7:3031-3052, 1982.

TRUNE DR. Influence of neonatal cochlear removal on the development of mouse cochlear nucleus: I. Number, size, and density of its neurons. J. Comp. Neurol. 209:409-424, 1982a.

TRUNE DR. Influence of neonatal cochlear removal on the development of mouse cochlear nucleus: II. Dendritic morphometry of its neurons. J. Comp. Neurol. 209:425-434, 1982b.

Waltzman SB, Cohen NL, Shapiro WH. Effects of chronic electrical stimulation on patients using a cochlear prosthesis. Ann. Otolaryngol. Head Neck Surg. 105:797-801, 1991.

Wang Y-X, Wenthold RJ, Otlerson OP, Petralia RS. End bulb synapses in the anteroventral cochlear nucleus express a specific subset of Ampa-type glutamate receptor subunits. J. Neurosci. 18:1148-1160, 1998.

WARR WB. Parallel ascending pathways from the cochlear nucleus: Neuroanatomical evidence of functional specialization. Contrib. Sens. 7:1-38, 1982.

WENTHOLD RJ. Evidence for a glycinergic pathway connecting the two cochlear nuclei: an immunocytochemical and retrograde transport study. Brain Res. 415:183-187, 1987.

Wenthold RJ, Hunter C, Petralia RS. Excitatory amino acid receptors in the rat cochlear nucleus. In: Merchan MA, Juiz JM, Godfrey DA, Mugnaini E (eds) The Mammalian Cochlear Nuclei: Organization and Function Plenum Press. New York, pp 179-194, 1993.

West CD, Harrison JM. Transneuronal cell atrophy in the deaf white cat. J. Comp. Neurol. 151:377-398, 1973.

WolfF D. Three generations of deaf white cats. J. Hered. 33:39-43, 1942.

YIN TCT, Chan JCK. Neural mechanisms underlying interaural time sensitivity to tones and noise. In: Edelman GM, Gall WE, Cowan WM (eds) Auditory Function: Neurobiological Bases of Hearing. John Wiley and Sons Inc., New York, pp 385-430, 1988.

Young ED, Shofner WP, White JA, Robert J-M, Voigt HF. Response properties of cochlear nucleus neurons in relationship to physiological mechanisms. In: Edelman GM, Gall WE, Cowan WM (eds) Auditory Function: Neurobiological Bases of Hearing. John Wiley and Sons Inc., New York. pp 277-312, 1988.

Zirpel L, Janowiak MA, Veltri CA, Parks TN. AMPA receptor-mediated, calcium-dependent CREB phosphorylation in a subpopulation of auditory neurons surviving activity deprivation. J. Neurosci. 20:6267-6275, 2000. 